\title{
Improving Enterprise Production Management System on the Basis of Lean Production
}

\author{
Sedelnikova Irina ${ }^{1}$, Fedorov Oleg $^{2}$, Yakusheva Alla ${ }^{1}$ \\ ${ }^{1}$ Department of Finance and Legal Regulation of Financial Markets, Nizhny Novgorod Institute of Management, Nizhny Novgorod, Russia \\ ${ }^{2}$ Department of Management Innovation, Nizhny Novgorod State Technical University N. A. R. E. Alekseev, Nizhny Novgorod, Russia
}

Email address:

sedelnikova@inbox.ru (S. Irina)

\section{To cite this article:}

Sedelnikova Irina, Fedorov Oleg, Yakusheva Alla. Improving Enterprise Production Management System on the Basis of Lean Production. International Journal of Economics, Finance and Management Sciences. Vol. 7, No. 6, 2019, pp. 210-214.

doi: $10.11648 /$ j.ijefm.20190706.15

Received: November 2, 2019; Accepted: December 11, 2019; Published: December 12, 2019

\begin{abstract}
The modern Russian machine industry is characterized by low efficiency and a low level of competitiveness in comparison with the foreign one. The implementation of Lean production concept in Russian industrial enterprises is one of the ways to solve this problem. The article analyzes process of improving enterprise production activities using Lean production concept. We used an Internet survey instrument to collect responses from Russian firms about the reasons for Lean production implementation. Despite a rich literature on Lean production, there are limited researches on the features of this concept implementation process in Russia. Many Russian companies allocate significant resources to implementing Lean production on the manufacturing shop floor, but underestimate the role of staff. Moreover, Lean tools are actually forced, Russian firms create atmosphere of fear that contradicts Lean idea itself. Thus in the article the role of human factor in Lean technologies implementation is considered. In the course of this research, the role of staff in Lean production implementation at six Nizhny Novgorod enterprises was analyzed. The situation turned out to be quite similar. Therefore, as an example, we consider one of the machine industry enterprises in more detail. We used a survey instrument and conducted survey of workers on the topic "Organization and management of production activities in Shop Floor N1". The questionnaire consisted of 30 questions including both open-close and multiple choice questions. A shop floor staff survey revealed serious problems that had not been clearly identified and formulated before. We tested our hypothesis that an appeal to the employees is not a formal attribute of Lean production. We found that it is an effective tool, the use of which allows management to identify many hidden losses and eliminate them using a minimum amount of financial resources, increase staff motivation as well as maintain creative atmosphere. Overall, our research suggests that Russian companies can get more out of their Lean implementations if they change the attitude of the staff.
\end{abstract}

Keywords: Lean Production, Losses, Perfection Process, Staff Involvement, Lean Production Tools, Visualization, 5s System

\section{Introduction}

At present, one of the most significant problems of Russian manufacturing enterprises is low efficiency and, as a result, a low level of competitiveness in comparison with foreign companies. This situation is typical for many sectors of the domestic industry. Moreover, it is especially crucial for machine industry, since it produces and maintains machines for consumers, the industry, and most other companies in the economy, serving as a basis for scientific and technological development of the country.

Problem analysis of modern Russian machine industry was carried out by Tatarskih and Fedorov [1]. Also directions of advanced technological development of domestic machine industry were developed and a set of measures necessary to solve the revealed problems was presented [1]. In addition to proposed measures, it is possible to recommend more active use of modern approaches to production systems construction, in particular "Lean production" concept, which in recent years has become increasingly popular in Russia.

Lean production has a positive impact on the measures of companies' operational performance [2-3]. A detailed analysis of Lean production tools was presented, for example, by Sundar et al. [4]. They also developed a 
roadmap for implementation of the concept in industrial enterprises business practice [4]. Lean technologies reduce costs, improve quality and speed of product delivery to consumers, and, ultimately, bring competitive advantage to business.

\section{Lean Production Implementation in Russian Companies}

Lean manufacturing has been introduced into Russian

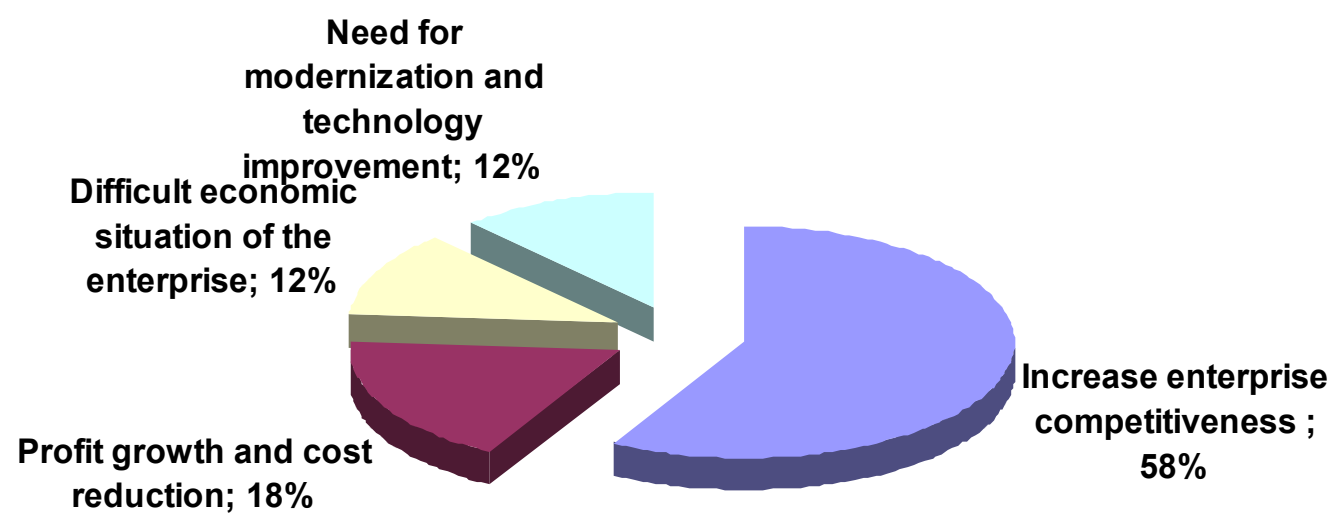

Figure 1. The survey results devoted to the reasons for Lean production implementation in Russian enterprises.

Other reasons (profit growth and cost reduction, the need for modernization and technology improvement, difficult economic situation of the enterprise) were mentioned significantly rarer.

At present, the production systems of GAZ [5], KAMAZ [6], Rosatom [7], Sberbank [8], etc. have been established and are functioning efficiently on the basis of Lean production concept. Other Russian companies have begun to work actively in the same direction, successfully advancing their activity.

However, when establishing lean manufacturing systems in domestic companies, various obstacles of endogenous and exogenous nature arise [9], as well as problems associated with eliminating a large number of causes of losses [10], Russian mentality peculiarities, insufficient adaptation of the concept for Russia, and a misunderstanding of its essence, using only individual tools, and not the approach as a whole [11]. Moreover, when analyzing the difficulties of implementing Lean production in Russian business, it turned out that one of the main problems is staff resistance as well as lack of personal involvement into the process of improving production systems and introducing lean technologies [11].

\section{The Role of Staff Involvement into Lean Production}

Indeed, ordinary employees play a key role in Lean production implementation [12]. This approach encourages operators to solve their own workplace problems [13]. The success of the concept implementation to a large extent business practice over the past decade and a half, and the process is significantly delayed compared to foreign companies which have accumulated about half a century experience in using lean technologies. The authors carried out a survey on the Internet of representatives of forty Russian companies implementing Lean production. It showed that the main incentive (58\% of respondents) to introduce the concept was the ability to increase enterprise competitiveness (Figure 1). depends on their motivation, creative approach to solving problems, involvement in the process of improving production activities. We can even talk about integration of human factor and technical systems [14].

However, in Russia, the human factor in Lean production is underestimated. This is primarily due to authoritarian style of management in many companies, especially in public sector. At the same time, Lean production tools are actually forced, employees are punished for non-fulfillment of any requirements, companies create atmosphere of fear that contradicts Lean idea itself. There is a huge distance between management and employees. In addition, one may note reluctance of top management to descend "from heaven" and turn their attention to the needs of employees. These problems are often exacerbated by a gigantic pay gap between managers and workers who receive remuneration for their work, making it barely possible to make ends meet, which leads to low motivation and a formal approach to the requirements of Lean production methods implementation. At the same time, staff involvement into improving production system process is a key element of Lean technologies but, for these reasons, seems to be the greatest impediment to its implementation in Russian companies.

In this regard, the study of direct participation of employees in identifying problems and developing proposals for improving processes seems relevant and significant. Changing approaches towards workers and turning to their direct assessment of the situation, which is usually based on common sense, are extremely important and deserve 
attention. It should also be noted that the improvement of production management system based on employees' proposals in most cases does not require any significant financial investments.

In the course of this research, the role of staff in Lean production implementation at six Nizhny Novgorod enterprises was analyzed. The situation turned out to be quite similar. Therefore, as an example, we consider one of the machine industry enterprises in more detail.

\section{Summary of the Enterprise Activity}

At one of machine industry plants in Nizhny Novgorod, the first stage of Lean production has already been implemented. The manufacturing is based on a pull system. It means that manufacturing program of each unit is determined by the size of subsequent unit order. Control system sets the task only for the final link in the production technological chain. Each subsequent shop floor depends on the previous one and provides the order to it, that is, each shop floor manufactures products exactly by order of the following shop floor.

We will consider control system improvement with the help of Lean production using the example of shop floor N1, which is the first link in the supply chain. We should note the important role of blank production in ensuring effectiveness of the entire manufacturing enterprise as a whole.

Shop floor N1 is divided into two sections. The assembly and welding section pulls workpieces and parts from the cutting and blank production section for their subsequent processing, that is, the activity of all other technological links depends on the situation in the cutting and blank production section. If existing problems are effectively solved on this site, this will lead to improvement of situation of the plant as a whole. At the cutting and blank production section, cutting various configuration parts from a metal sheet and cutting of bar stock and pipes into piece blanks are performed. The following types of technological operations are carried out here: straightening of metal sheets, laser, plasma, waterjet, milling, cutting with guillotine shears and a band saw, stamping, bending, rolling, etc.

Lean production is aimed both at identifying and eliminating losses, as well as at implementing a program of continuous improvements, mainly due to involvement of specific staff members directly implementing certain operations. The level of productivity, product quality and timing of sending parts to recipient shop floors depends on the effective management. At the same time, employees are an important source of information and the main active force in carrying out any changes at the enterprise. Despite Lean technologies implementation at the enterprise, there was no active staff involvement into improvement process, that is, staff potential was not fully engaged, which means that many problems have not been completely solved. In this regard, it was necessary to conduct a study of situation assessment in the shop floor to reveal to what extent ordinary employees are able to analyze problems, identify sources of hidden losses, bottlenecks in the shop floor and also develop proposals to solve these problems.

\section{Results of Stuff Survey}

In the course of the study, a survey of workers was conducted on the topic "Organization and management of production activities in Shop Floor N1".

The questionnaire consisted of 30 questions including both open-close and multiple choice questions and provided employees with an opportunity to anonymously talk about the difficulties that arise in their work, to express wishes and suggestions for improving the processes. 38 people were interviewed. We present the most interesting and significant results of this survey with suggestions to improve activities.

Lean production implementation, as a rule, begins with $5 \mathrm{~S}$ "Clean and tidy workplace" system introduction. When asked whether employees knew about this system, 90\% answered in the affirmative, $20 \%$ not only knew, but also completed $5 \mathrm{~S}$ training, but only $10 \%$ wanted to use it in their work. Thus, we can conclude that Lean basic tool - the $5 \mathrm{~S}$ system - has not yet received proper development on the site, so this situation needs to be fixed.

The questionnaire had also a question related to use of visualization as a Lean production tool in the shop floor. The role of visualization was rated positively. According to workers, visualization helps to navigate the shop floor among various types of equipment, racks and cabinets. The marking on the floor contributes to rational movement of the facility vehicles. Visualization also positively affects reduction and prevention of traumatic situations, ensures safety of internal logistics of the shop floor. The use of visualization at workplaces, on racks and in cabinets reduces time of searching for parts and blanks, as well as documentation. Information stands, plates and cards with the name of production facilities presence makes it easy to navigate the shop floor.

A proposal was made to further improve the use of this tool related to color marking of shelves of the site finished products. Orders for the production of parts and blanks arrive at the site in the form of sets. In order to be able to immediately determine whether the order has been fully completed or not, you should use different color markers for the racks where these sets of finished products are stored. Such visualization fasters search for completed orders and speeds up the process of supplying finished parts to the welding assembly section of the shop floor and to other recipient shop floors.

The survey also asked about the desire to work and willingness of employees to change. With the exception of two people, the rest answered in the affirmative. Everyone wants to work for the good of the enterprise, provided that production process is effectively organized, workplace comfort is ensured, basic salary and remuneration for overtime hours are stable.

Respondents were also asked to comment on their 
concerns regarding work process. The answers revealed that the most serious problem was a large number of unplanned urgent tasks that need to be done quickly. Often, either the work is done on time, but this is to detriment of quality, or it is impossible to complete the task by the indicated time, and the deadlines will be violated. In addition, such tasks exacerbate the situation as a whole and adversely affect the work that is being done on schedule. As a result, this can lead to productive inefficiency, deterioration in work quality and a slowdown in other work processes.

Other problems were also identified:

1. a large amount of accompanying documentation for parts and blanks, while you have to rework route sheets due to changes and updates to technology program, as well as spend time searching for them;

2. a lot of unnecessary movements, unnecessary work, not related to official staff responsibilities;

3. lack of tools;

4. occurrence of faults and absence of measures to prevent them;

5. equipment breakdown due to violation of scheduled maintenance.

The following were named as suggestions for improvement:

1. rational organization of the shop floor, so that each employee is engaged only in his own business;

2. reduction in the volume of workflow associated with maintaining and filling out route and accompanying documentation;

3. an objective manager's assessment of work terms and quality when issuing a task to an employee;

4. strict adherence to equipment maintenance schedules [15].

The implementation of these proposals, according to experts, can significantly improve the situation in the shop floor, which affects the performance of the entire enterprise as a whole. It should be noted that employees were enthusiastic about the questionnaire, feeling the importance of their vision of the situation, responsibly approached the questionnaire and tried to objectively answer the questions asked.

\section{Conclusion}

Establishing Lean production is a complex process, for which it is necessary to use a systematic approach, involving full range of lean tools use. At the same time, one of the main problems, especially typical to Russian companies, is insufficient staff involvement, and in many cases there is even resistance to changes from employees related to the concept implementation.

A shop floor staff survey revealed serious problems that had not been clearly identified and formulated before. The proposals to solve them were developed. That is, an appeal to the employees is not a formal attribute of Lean production, an event "for show", but is an effective tool, the use of which allows management to identify many hidden losses and eliminate them using a minimum amount of financial resources, increase staff motivation as well as maintain creative atmosphere. At the same time, the main task of managers at the next stage is to implement all these proposals to improve management not only in this area, but also at the enterprise as a whole.

\section{References}

[1] B. Y. Tatarskih, and O. V. Fedorov, "Organizational and economic problems of increasing the innovative potential of the machine industry of Russia," Bulletin of Samara state economic university, no. 3 (137), pp. 16-22, March. 2016.

[2] L. L. Negrão, M. Godinho Filho, and G. A. Marodin, "Lean practices and their effect on performance: a literature review, " Production Planning \& Control, vol. 28, no. 1, pp. 33-56, 2017.

[3] R. Shah, and P. Ward, "Lean manufacturing: context, practice bundles, and performance," Journal of Operations Management, vol. 21, pp. 129-149, 2003.

[4] R. Sundar, A. N. Balaji, and R S. Kumar, "A review on lean manufacturing implementation techniques," Procedia Engineering, vol. 97, pp. 1875-1885, 2014.

[5] Lean Thinking: GAZ Group [Online]. Available: http://www.up-

pro.ru/library/production_management/systems/berezhlivoe myshlenie_gruppa_gaz.html

[6] KAMAZ Lean Production [Online]. Available: http://kamaz.ru /press/releases/berezhlivoe_proizvodstvo_kamazov/?sphrase_i $\mathrm{d}=223394$

[7] Implementation of Rosatom Production System [Online]. Available: http://www.rosatom.ru/employee/actualproject/

[8] Sberbank development strategy for 2014-2018 [Online]. Available:

https://www.sberbank.ru/common/img/uploaded/files/sberban kdevelopmentstrategyfor2014-2018.pdf

[9] V. V. Iashchenko, and E. D. Orlova, "Obstacles to the Introduction of Lean Production in Russian Electrotechnical Enterprises," in Proc. IEEE Conference of Russian Young Researchers in Electrical and Electronic Engineering (EIConRus), Moscow, St. Petersburg, Russia, 2019. pp. 14031405. DOI: 10.1109/EIConRus.2019.8657146

[10] S. Kazantseva, "Problems of introduction of lean manufacturing at Russian enterprises," Creative Economy, vol. 8, no 12, pp. 90-98, Dec. 2014.

[11] I. M. Sedelnikova, "Analysis of the Lean production implementation process in Russian companies," Scientific Notes, vol. 15, pp. 100-109, Nizhny Novgorod Institute of Management - Branch of the Russian Presidential Academy of National Economy and Public Administration (RANEPA), 2017, Nizhny Novgorod, Russia.

[12] I. K. Dibia, and S. Onuh, "Sustaining the Human Resource 'the real quality' in Lean Production system," in Proc. International Conference on Education and Management Technology, Chengdu, China, 2010, pp. 297-300. DOI: 10.1109/ICEMT.2010.5657650 
[13] K. L. Sim, and J. W. Rogers, "Implementing lean production systems: barriers to change." Management Research News, Vol. 32 No. 1, pp.37-49, 2008.

[14] A. Ayough, and F. Farhadi, "How to Make Lean Cellular Manufacturing Work? Integrating Human Factors in the Design and Improvement Process," IEEE Engineering
Management Review, vol. 47, no. 1, pp. 99-105, March 2019. DOI: 10.1109/EMR.2019. 2898952

[15] V. P Bochkarev., O. V. Fedorov, and V. V. Fufaev, Effectiveness of controlling the structure of electrical equipment during technical re-equipment, Glass and Ceramics, vol. 44, no. 9, pp. 376-379, Sept. 1988. 